\title{
Predictors of Differences in Vitamin D Levels in Children and Adolescents and Their Relation to Endurance Performance
}

\author{
Lena Lämmle ${ }^{a}$ Karin Bergmann ${ }^{c}$ Klaus Bös ${ }^{d}$ Berthold Koletzko ${ }^{b}$ \\ ${ }^{a}$ Department of Sport Psychology, Technische Universität München, ${ }^{b}$ Dr. von Hauner Children's Hospital, \\ Ludwig Maximilians University of Munich, Munich, ${ }^{C}$ Food Relations, Puchheim, and ${ }^{\mathrm{d}}$ Institute of Sport and \\ Sport Sciences, Karlsruhe Institute of Technology, Karlsruhe, Germany
}

\section{Key Words}

Adolescents $\cdot$ Body mass index $\cdot$ Children $\cdot$ Endurance performance $\cdot 25$-Hydoxyvitamin $D \cdot$ Sociodemographic factors

\begin{abstract}
Aims: The present study investigated whether sociodemographic factors and physical activity (PA) are associated with differences in serum 25-hydroxyvitamin D [25(OH)D] levels and whether these differences are associated with varying levels of endurance performance and body mass index (BMI) in children and adolescents. Subjects and Methods: Path analyses were based on data of a nationwide, cross-sectional German Health Interview and Examination Survey for Children (KiGGS; 2003 until 2006) for 25(OH)D and the embedded 'motor function module' for PA and endurance performance. The data were collected from 3,437 children and adolescents aged $6-17$ years clustered in three age groups: 6-10, 11-13 and 14-17 years. Results: PA is affected by socioeconomic status and (non-)immigration background, $25(\mathrm{OH}) \mathrm{D}$ is only affected by (non-)immigration background and only in childhood. PA and 25(OH)D were not associated in those aged 11-13 years. In adolescence, lower 25(OH)D levels are associated with lower endurance performance and
\end{abstract}

\section{KARGER}

Fax +4161306 1234

E-Mail karger@karger.ch

www.karger.com
(C) 2012 S. Karger AG, Basel

$0250-6807 / 13 / 0621-0055 \$ 38.00 / 0$

Accessible online at:

www.karger.com/anm a higher BMI. Conclusions: Our results did not reveal a universally significant effect of sociodemographic factors on 25(OH)D. The association between 25(OH)D and endurance performance might reflect the effects of $25(\mathrm{OH}) \mathrm{D}$ on muscle function. Predictors of $25(\mathrm{OH}) \mathrm{D}$ status other than sunlight exposure and its health effects in the pediatric age group should be explored further.

Copyright $\odot 2012$ S. Karger AG, Basel

\section{Introduction}

The impact of 25-hydroxyvitamin D [25(OH)D]) not only on bone health but also on other health outcomes is increasingly recognized [1-3]. Several studies in adults have found relationships between $25(\mathrm{OH}) \mathrm{D}$ and muscle function, an increased risk of falls $[4,5]$ as well as gastrointestinal disorders [6] and malignancies [7]. Little is known on the health effects of vitamin $\mathrm{D}$ in children and adolescents beyond the association of higher $25(\mathrm{OH}) \mathrm{D}$ levels with better bone health [8]. This question is of considerable interest given that numerous studies reported far less than optimal 25(OH)D levels in children and adolescents in different populations [9-18]. In the present study, we aimed to characterize not only the causes but 
also the consequences of differences in 25(OH)D levels in German children and adolescents. We aimed at exploring associations of sociodemographic factors [socioeconomic status (SES) and (non-)immigrant background] as well as physical activity (PA) with $25(\mathrm{OH}) \mathrm{D}$ levels, and potential relationships of $25(\mathrm{OH}) \mathrm{D}$ with endurance performance and body mass index (BMI). We considered different pediatric age groups separately because of previously reported age differences for PA, endurance performance [19] and 25(OH)D [20].

\section{Methods}

\section{Subjects}

The subjects studied represent a subgroup of the 'German Health Interview and Examination Survey for Children and Adolescents' (KiGGS) conducted between May 2003 and May 2006. The KiGGS survey is a nationwide, cross-sectional study on the health status of children and adolescents aged 4-17 years which was conducted by the Robert Koch Institute in Berlin and funded by the federal government [21]. A stratified two-stage probability sampling procedure was applied to select the subgroup participating in the 'motor function module' with detailed measurements of PA and endurance. The primary sample units were research sites in 150 communities throughout Germany. Subsequently, children and adolescents aged 4-17 years were randomly selected from the official registers of local residents' registration offices of these communities [22]. Participation was voluntary. The response rate was $66.6 \%$ with $5.3 \%$ quality-neutral dropouts, and 4,529 children and adolescents (2,244 girls and 2,285 boys) aged 4-17 years (mean \pm SD: $9.45 \pm 4.01$ years) participated [23]. In consideration of seasonal variations in $25(\mathrm{OH}) \mathrm{D}$ levels, equal random samples were drawn over the four seasons of the year. Therefore, the analyses presented here are thus based on a sample of 3,437 children and adolescents. Participants were categorized into three age groups: 6-10 years (primary school), 11-13 years (lower secondary school) and 14-17 years (upper secondary school). Children were helped to fill out the questionnaires described below [22].

\section{Socioeconomic Status}

SES information was based on the unweighted mean score of the parents' information on their school education and professional qualifications, occupation and net household income. Each scale ranged from 1 to 7 points. Data on the parent with the higher status or, in case of divorced parents, the status of the parent the child lived with was used [24]. Migrants were defined as children born outside Germany, or with at least one parent born outside Germany, or with both parents having non-German citizenship.

\section{Physical Activity}

PA was assessed with a questionnaire containing 35 previously validated items involving the duration, intensity and frequency of PA in leisure time, school and sport clubs in the past year based on existing questionnaires [22]. The test-retest reliability in the previous 7-day longitudinal study ranged from $r_{\mathrm{tt}}=0.72$ (PA in leisure time) to $r_{t t}=0.93$ (PA in sport clubs). Construct validityrelated evidence was gathered by looking at the correlation with a multisensory electronic monitor including a biaxial accelerometer measuring PA (SenseWear Pro 2). Results have shown higher correlations with this monitor and the regarded types of PA $\left(r_{\min }=0.56, r_{\max }=0.66\right)$ than with other PA questionnaires [25].

In accordance with international recommendations (President's Council on Physical Fitness and Sports 2008 [26, 27]) for activity guidelines with at least 60 min of moderate to vigorous activity daily, a PA parcel was built. For school, leisure time and sport club activity, only time spent from at least moderate PA (in min) was considered: number of school sport hours $\times 30 \mathrm{~min}+$ frequency of first sport $x$ duration of first sport $x$ number of months first sport is undertaken/12 (months a year) + frequency of second sport $\times$ duration second sport $\times$ number of months second sport is undertaken/12 (months a year) + frequency of third sport $\times$ duration third sport $\times$ number of months third sport is undertaken/12 (month a year) + frequency of fourth sport $\times$ duration fourth sport $\times$ number of months fourth sport is undertaken/12 (months a year). Sustained moderate to vigorous PA which was associated with positive health outcome was documented [28].

\section{Endurance}

A bicycle ergometer test was used to assess fitness performance and heart rate response. The test starts with a calculated initial load of $0.5 \mathrm{~W} \cdot \mathrm{kg}^{-1}$ body weight. This is then followed by an increase in load of a further $0.5 \mathrm{~W} \cdot \mathrm{kg}^{-1}$ body weight every $2 \mathrm{~min}$. The test is then discontinued for any of the following three reasons: (1) when heart rate load reaches 190 (6-10 years) or 180 (1117 years) b.p.m.; (2) when the frequency of rotation decreases below $50 \mathrm{rpm}$ for a period of at least $20 \mathrm{~s}$, or (3) when the subject stops due to exhaustion. The variable used for analysis is the wattage associated with a heart rate of 170 divided by the body weight (relative PWC 170). Since the health-related physical fitness should be assessed, PWC 170 was chosen as an internationally established endurance criterion and not the maximum heart rate load [29].

\section{Body Mass Index}

Height (stature) was measured in the standing position with a calibrated portable Holtain stadiometer and an accuracy of 0.1 $\mathrm{cm}$. Body weight (mass) was assessed with participants in their underwear on a calibrated scale with an accuracy of $0.1 \mathrm{~kg}$. BMI was calculated as body weight $(\mathrm{kg}) /$ height $\left(\mathrm{m}^{2}\right)$.

\section{Serum 25(OH)D}

Venous blood samples were collected from non-fasting participants and serum $25(\mathrm{OH}) \mathrm{D}(\mathrm{nmol} / \mathrm{l})$ was assessed using the LIASON chemiluminescence immunoassay method (CLIA/DiaSorin) [30]. Severe vitamin D deficiency was defined as $25(\mathrm{OH}) \mathrm{D}$ concentration $<12.5 \mathrm{nmol} / \mathrm{l}$, moderate deficiency as 12.5 to $<25$ $\mathrm{nmol} / \mathrm{l}$, mild vitamin D deficiency as 25 to $<50 \mathrm{nmol} / \mathrm{l}$, and sufficiency as $\geq 50 \mathrm{nmol} / \mathrm{l}$ [31]. As expected, serum $25(\mathrm{OH}) \mathrm{D}$ concentrations were highest in summer $(66 \mathrm{nmol} / \mathrm{l})$, followed by autumn (54 nmol/l), spring ( $37 \mathrm{nmol} / \mathrm{l})$ and winter $(33 \mathrm{nmol} / \mathrm{l})$. The lowest serum $25(\mathrm{OH}) \mathrm{D}$ concentrations were found in 11- to 13 -year-old females in winter (mean $29 \mathrm{nmol} / \mathrm{l}$ ) and 14 - to 17 -yearold male adolescents in spring (mean $32 \mathrm{nmol} / \mathrm{l}$ ). The frequency 
distribution in the $25(\mathrm{OH}) \mathrm{D}$ classification - in categories of serious/moderate, mild and no deficiency - demonstrated that a total of $22 \%$ of subjects had moderate (or serious) deficiency, $42 \%$ a mild deficiency and 36\% no vitamin D deficiency (table 1). In the 11 - to 13 -year-old group, only $30 \%$ showed a value $>50 \mathrm{nmol} / \mathrm{l}$.

\section{Statistical Analysis}

Descriptive statistics and regression analyses were calculated using IBM SPSS Statistics 19.0 (New York, N.Y., USA). The significance level was set at $\mathrm{p} \leq 0.05$. As seasonal influences were treated as covariates in this study, regression analyses with seasonal influences as predictors for each measure considered as criterion were conducted and the standardized residuals were saved and used for path analyses. Path analyses to examine the interplay of all considered variables and bivariate correlations and to explore moderation or mediation effects were conducted with IBM SPSS AMOS 19.0 using a robust maximum likelihood algorithm. Because of missing data, the assumption of multivariate normality could not be tested. Cutoffs used to assess the model fit in addition to the significance of the $\chi^{2}$ value were based upon the suggestions by $\mathrm{Hu}$ and Bentler [32] and Beauducel and Wittmann [33]. Consequently, we looked at the root mean square error of approximation (RMSEA), as recommended by $\mathrm{Hu}$ and Bentler [32], and, additionally, on the comparative fit index (CFI), as recommended by Beauducel and Wittmann [33]. According to $\mathrm{Hu}$ and Bentler [32], approximate cutoff values of RMSEA $\leq 0.08$ and CFI $\geq 0.95$ are appropriate. Missing data were imputed with the full information maximum likelihood algorithm [34]. Even when the assumption of multivariate normality is violated, the full information maximum likelihood algorithm provides relatively good estimations compared to deletion or mean imputation methods [35]. The proportion of missing item responses for each scale ranged from 0.0 to $1.0 \%$. Overall lack of response was $1.7 \%$ (409 of 24,059 responses). Multigroup analyses were calculated for children and adolescents. A change in CFI $>0.002$ was regarded as a significant difference between the groups considered [36].

\section{Results}

\section{Descriptive Statistics and Bivariate Path Correlations}

Tables 1 and 2 provide descriptive statistics and bivariate correlations for the underlying variables of the path analyses. SES and (non-)immigrant background were similar for all age groups. Adolescents were more active than children and consequently revealed higher endurance performances, but also higher BMI scores. 25(OH)D levels were lowest for adolescents aged 11-13 and highest for children. SES and (non-)immigrant background correlated significantly with $\mathrm{PA}, 25(\mathrm{OH}) \mathrm{D}, \mathrm{BMI}$ (only SES) and endurance performance. PA showed significant correlations to all body measures. 25(OH)D correlated significantly with BMI but not with endurance performance. A significant association between BMI and endurance was observed.

Serum 25(OH)D and Endurance

Performance
Table 1. Descriptive statistics (age and gender) for SES and immigration status, $\mathrm{PA}, 25(\mathrm{OH}) \mathrm{D}, \mathrm{BMI}$ and endurance

\begin{tabular}{|c|c|c|c|}
\hline & \multicolumn{3}{|c|}{ Mean \pm SD or $\%$} \\
\hline & $6-10$ years & $11-13$ years & $14-17$ years \\
\hline Age, years & $8.31 \pm 1.47$ & $12.5 \pm 0.88$ & $15.79 \pm 1.08$ \\
\hline \multicolumn{4}{|l|}{ Gender } \\
\hline male/female & $51 / 49$ & $53.4 / 46.6$ & $49.5 / 50.5$ \\
\hline SES & $2.03 \pm 0.71$ & $1.93 \pm 0.71$ & $2.02 \pm 0.70$ \\
\hline \multicolumn{4}{|l|}{$(\mathrm{N}-) \mathrm{IB}$} \\
\hline IM/NIM & $10.2 / 89.1$ & $10.5 / 89.5$ & $10.5 / 89.4$ \\
\hline $\mathrm{PA}, \min$ & $141.54 \pm 90.78$ & $182.45 \pm 116.57$ & $180.95 \pm 143.54$ \\
\hline $25(\mathrm{OH}) \mathrm{D}, \mathrm{nmol} / \mathrm{l}$ & $50.54 \pm 33.94$ & $44.61 \pm 25.63$ & $47.07 \pm 31.73$ \\
\hline BMI & $16.86 \pm 2.64$ & $19.47 \pm 3.62$ & $21.68 \pm 3.81$ \\
\hline \multicolumn{4}{|l|}{ Endurance, } \\
\hline $\mathrm{W} \cdot \mathrm{kg}^{-1}$ & $1.94 \pm 0.48$ & $2.02 \pm 0.48$ & $2.10 \pm 0.50$ \\
\hline
\end{tabular}

The SES scale ranged from 1 to 7 points. $(\mathrm{N}-) \mathrm{IB}=$ Immigrant (IM)/nonimmigrant (NIM) background.

Table 2. Bivariate correlations for SES and immigration status, $\mathrm{PA}, 25(\mathrm{OH}) \mathrm{D}, \mathrm{BMI}$ and endurance

\begin{tabular}{llllll}
\hline \multicolumn{5}{l}{ Bivariate correlations } \\
\cline { 2 - 6 } & (N-)IB & PA & $25(\mathrm{OH}) D$ & BMI & endurance \\
\hline SES & $-0.19^{\mathrm{a}}$ & $0.10^{\mathrm{a}}$ & $0.08^{\mathrm{a}}$ & $-0.12^{\mathrm{a}}$ & $0.11^{\mathrm{a}}$ \\
$(\mathrm{N}-)$ IB & & $-0.07^{\mathrm{a}}$ & $-0.10^{\mathrm{a}}$ & 0.02 & $-0.07^{\mathrm{a}}$ \\
PA & & & $0.04^{\mathrm{b}}$ & $0.17^{\mathrm{a}}$ & $0.32^{\mathrm{a}}$ \\
25(OH)D & & & & $-0.10^{\mathrm{a}}$ & 0.03 \\
BMI & & & & & $0.18^{\mathrm{a}}$ \\
\end{tabular}

The SES scale ranged from 1 to 7 points. $(\mathrm{N}-) \mathrm{IB}=($ Non-)immigrant background. ${ }^{\mathrm{a}} \mathrm{p}<0.001 ;{ }^{\mathrm{b}} \mathrm{p}<0.05$.

\section{Model Fit}

Multigroup analyses (fig. 1; statistical analysis) revealed differences for the three age groups, with an acceptable model fit $\left[\chi^{2}(15)=81.589, \mathrm{p}<0.001\right.$, RMSEA $=$ 0.045 (90\% confidence interval: $0.036-0.055), C F I=0.90$, $\Delta \mathrm{CFI}=-0.051]$.

\section{Correlations}

Ages 6-10. Rates of PA are higher for both non-immigrant children background $(\mathrm{a}=-0.09, \mathrm{p}=0.001)$ and those with higher SES $(\mathrm{a}=0.14, \mathrm{p}<0.001)$. Similarly $25(\mathrm{OH}) \mathrm{D}$ levels for non-immigrant children were higher $(\mathrm{a}=-0.12, \mathrm{p}<0.001)$, but no associations were found with SES $(\mathrm{a}=0.05, \mathrm{p}=0.10)$. Higher PA was associated with

Ann Nutr Metab 2013;62:55-62 
Fig. 1. Path model to describe the relationship between measured variables (compare text). Explained variance $\left(\mathrm{R}^{2}\right)$ and path values (a) are shown. Unstandardized solution. $\mathrm{E}=$ Endurance; $(\mathrm{N}-) \mathrm{IB}=$ (non-) immigrant background. Standard $=6-10$ years of age; italicized $=11-13$ years of age; bold $=14-17$ years of age.

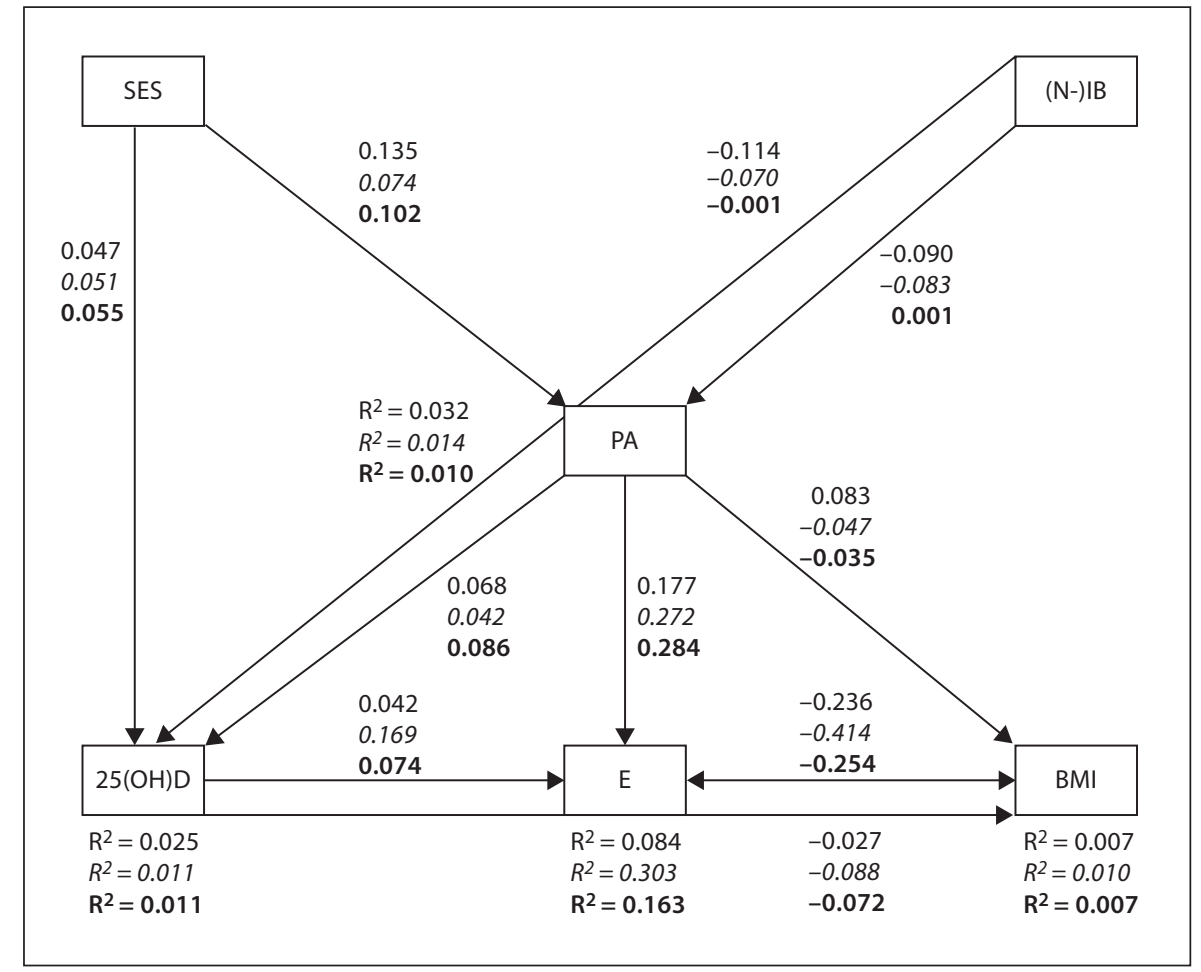

higher BMI $(\mathrm{a}=0.08, \mathrm{p}<0.01)$, with higher $25(\mathrm{OH}) \mathrm{D}$ levels $(\mathrm{a}=0.07, \mathrm{p}<0.05)$ and with a higher level of endurance $(\mathrm{a}=0.18, \mathrm{p}<0.001)$, which was also directly associated with a higher BMI $(\mathrm{a}=-0.24, \mathrm{p}<0.001) .25(\mathrm{OH}) \mathrm{D}$ was neither associated with BMI $(\mathrm{a}=-0.03, \mathrm{p}=0.33)$ nor with endurance $(a=0.04, p=0.15)$. SES and (non-)immigrant background explained $3.2 \%$ of the PA variance and $2.5 \%$ of the $25(\mathrm{OH}) \mathrm{D}$ level variance was explained by sociodemographic variables and PA. PA explained $0.8 \%$ of the variance in BMI. PA, 25(OH)D and BMI explained $8.4 \%$ of the variance of endurance. The specific, explained variance of $25(\mathrm{OH})$ D on endurance performance amounts to $0.4 \%$.

Ages 11-13. The PA of younger adolescents aged 1113 years is associated with higher SES $(\mathrm{a}=0.07, \mathrm{p}<0.05)$ and non-immigrant background $(\mathrm{a}=-0.08, \mathrm{p}<0.05)$. $25(\mathrm{OH}) \mathrm{D}$ was neither associated with (non-)immigrant background $(\mathrm{a}=-0.07, \mathrm{p}=0.06)$ nor with SES $(\mathrm{a}=0.05$, $\mathrm{p}=0.15)$ and PA $(\mathrm{a}=0.04, \mathrm{p}=0.26)$. BMI was unrelated to PA $(\mathrm{a}=-0.05, \mathrm{p}=0.20)$ but correlated with $25(\mathrm{OH}) \mathrm{D}$ [with a lower BMI for higher $25(\mathrm{OH}) \mathrm{D}$ levels; $\mathrm{a}=-0.09$, $\mathrm{p}<0.05]$. Endurance performance was positively associated with PA $(\mathrm{a}=0.27, \mathrm{p}<0.001)$ and $25(\mathrm{OH}) \mathrm{D}(\mathrm{a}=0.17$, $\mathrm{p}<0.001)$ and inversely with BMI $(\mathrm{a}=0.41, \mathrm{p}<0.001)$. SES and (non-)immigrant background explained 1.4\% of the PA variance, and $1.1 \%$ of the $25(\mathrm{OH}) \mathrm{D}$ level variance were explained by sociodemographic variables and PA. PA and $25(\mathrm{OH}) \mathrm{D}$ explained $1 \%$ of the variance of BMI [with $0.8 \%$ for $25(\mathrm{OH}) \mathrm{D}$ ]. PA, 25(OH)D and BMI explained $29.9 \%$ of the variance in endurance. The specific, explained variance of $25(\mathrm{OH}) \mathrm{D}$ on endurance performance amounts to $4.9 \%$.

Ages 14-17. In common with the other age groups, adolescents aged 14-17 with a higher SES were more physically active. Migration status was not associated with PA. The $25(\mathrm{OH}) \mathrm{D}$ levels were neither predicted by SES nor by migration status, but were predicted by PA [with a higher 25(OH)D level for more PA $(\mathrm{a}=0.09, \mathrm{p}<0.05)$ ]. BMI was not affected by PA, but a higher BMI was related to a lower 25(OH)D level. Endurance performance was greater with higher levels of 25(OH)D and PA but lower BMI. SES and (non-)immigrant background explained $1 \%$ of the PA variance, and $1.1 \%$ of the $25(\mathrm{OH})$ $\mathrm{D}$ level variance was explained by sociodemographic variables and PA. $25(\mathrm{OH}) \mathrm{D}$ explained $0.6 \%$ of the variance in BMI (the variance explained by PA is 0 ). PA, $25(\mathrm{OH}) \mathrm{D}$ and $\mathrm{BMI}$ explained $16 \%$ of the variance in endurance. The specific, explained variance of $25(\mathrm{OH}) \mathrm{D}$ on endurance performance amounts to $1.3 \%$. 


\section{Discussion}

This study shows that 25(OH)D levels are affected by (non-)immigrant background in children whereas PA is affected by SES in children and adolescents and by (non-) immigrant background in children and younger adolescents but not in those aged 14-17 years. Bivariate analysis showed an association between SES and 25(OH)D in children as well as of (non-)immigrant background with $25(\mathrm{OH}) \mathrm{D}$ in adolescents aged 11-13, which seems to result from multicollinearity. Thus, the specific effect sizes of SES or (non-)immigrant background on 25(OH)D seemed smaller than suggested by bivariate findings, emphasizing the need to consider both sociodemographic factors jointly. PA and 25(OH)D were not associated among adolescents aged 11-13 years. Thus, we cannot explain differences in $25(\mathrm{OH}) \mathrm{D}$ levels by (non-)immigrant background, SES or PA in adolescents aged 11-13 years. Of interest, associations of $25(\mathrm{OH}) \mathrm{D}$ with $\mathrm{BMI}$ and endurance performance were only observed in adolescents; however, in the bivariate analysis (but not in the path analysis) there was an association of $25(\mathrm{OH}) \mathrm{D}$ and endurance performance in children aged 6-10 years, which again seems to result from multicollinearity. Thus, the specific effects of $25(\mathrm{OH}) \mathrm{D}$ on endurance performance seem smaller than suggested by the bivariate correlations after controlling for BMI.

In addition to the known effect of the seasons on $25(\mathrm{OH}) \mathrm{D}$ levels [37], we found (non-)immigrant background to affect $25(\mathrm{OH}) \mathrm{D}$ levels in children but not in adolescents, which is of interest for future intervention studies. The impact of sociodemographic factors on $25(\mathrm{OH}) \mathrm{D}$ levels has been addressed only in a few studies, and findings were inconsistent [37-39]. For example, Räsanen et al. [38] found that sociodemographic factors, especially the number of children in the family and maternal age at child birth, were associated with total vitamin and vitamin D supplement intake. A seasonally adjusted multivariate analysis by Houghton et al. [37] showed higher levels of caregivers' education to be independently associated with lower $25(\mathrm{OH}) \mathrm{D}$ concentrations, possibly due to greater attempts to prevent unprotected sun exposure in their children. In the present analysis, we found no such associations between SES and $25(\mathrm{OH}) \mathrm{D}$ irrespective of age. However, there also seem to be effects of multicollinearity for SES and (non-)immigrant background on $25(\mathrm{OH}) \mathrm{D}$ suggesting that there is a need to consider both sociodemographic factors jointly. Of importance, such effects might explain the inconsistent findings of previous reports.

Serum 25(OH)D and Endurance Performance
The impact of (non-)immigrant background on children's PA levels observed in the present study was also reported by Green et al. [40], who found the greatest cross-cultural diversity within three generations among children. Other studies reported a higher prevalence of physical inactivity for certain groups of immigrants, which was also associated with socioeconomic differences $[41,42]$. Studies on the sole effect of SES on PA in children and adolescents revealed contradictory findings. However, more recent research has suggested lower levels of PA in families with lower SES [43, 44], which is in accordance with the present findings.

A previous study found PA to be related to $25(\mathrm{OH}) \mathrm{D}$ in children and adolescents [20]. In our study, higher levels of $25(\mathrm{OH}) \mathrm{D}$ were linked to higher levels of PA in children and adolescents aged 14-17 years, but not in those aged 11-13 years, which is difficult to explain but might be related to the many transitions occurring around puberty.

Hanson et al. [43] concluded that higher PA levels are correlated with higher levels of endurance. In contrast to our results, a lower BMI was previously found to be associated with higher PA levels in younger children [44]. A possible explanation is that not only PA level but also the extent of sedentary behavior and physical inactivity has a marked impact on BMI in children and adolescents [45]. In agreement with our findings, Deforche et al. [46] found a lower BMI associated with higher endurance levels in adolescents.

Besides PA, 25(OH)D also impacted on endurance of adolescents aged 11 years or older, with higher endurance levels for a more adequate supply of serum concentrations of $25(\mathrm{OH}) \mathrm{D}$. This agrees with earlier findings where schoolgirls aged 9-15 years with severe vitamin D deficiency had a significantly lower level of fitness $\left(\mathrm{VO}_{2 \max }\right)$ than the non-deficient group [47]. Another study revealed that among 54 healthy young females better cardiorespiratory fitness $\left(\mathrm{VO}_{2 \max }\right)$ was associated with higher serum 25(OH)D level [39]. Ardestani et al. [48] concluded that serum $25(\mathrm{OH}) \mathrm{D}$ levels predict $\mathrm{VO}_{2 \max }$ in adults, with the greatest effects in those with low PA levels.

In line with the previously reported inverse relationship of 25(OH)D and BMI [49], we also found such a relationship in adolescents but not in children. The underlying mechanisms are not fully known, but it is assumed that sequestration of vitamin $\mathrm{D}$ in body fat stores may be a contributing factor along with lower sunlight exposure among obese people [50]. Another reason for the positive association between $25(\mathrm{OH}) \mathrm{D}$ and physical endurance as

Ann Nutr Metab 2013;62:55-62 
well as lower BMI levels could be the presence of vitamin $\mathrm{D}$ receptors in the muscle fibers, which makes a physiological impact of vitamin D supply on muscle activity plausible. Randomized controlled trials in elderly people showed vitamin D to significantly reduce the number of falls, apparently due to enhanced neuromuscular function $[4,51]$. In a double-blind, placebo-controlled trial in Lebanese girls, vitamin D supplementation (2,000 IU/ day) showed a significant effect on musculoskeletal parameters and muscle mass especially during the premenarchal period [52]. Since a correlation between muscle function, muscle mass and bone mass is well documented across age groups $[48,53-55]$, it is tempting to speculate that part of the benefits of vitamin $\mathrm{D}$ on bone health might be mediated by its effects on musculoskeletal function. This conclusion has to be treated with caution, because there is an ongoing debate as to whether relevant vitamin $\mathrm{D}$ receptor-related genetic influences are also associated with physical performance $[56,57]$.

A limitation of our study is that analyses are not based on longitudinal data, hence no inferences on causality or development over time are possible. Furthermore, we did not consider various $25(\mathrm{OH}) \mathrm{D}$-related behaviors, such as dietary choices or use of sun blockers.

In summary, our findings reveal that while PA is affected by sociodemographic factors of SES and (non-)immigrant background [except for (non-)immigrant background for adolescents aged 14-17 years], 25(OH)D levels are only affected by (non-)immigrant background and only in childhood. There seemed to be multicollinearity for SES and (non-)immigrant background on 25(OH)D, therefore the commonalities among SES and (non-)immigrant background seem relevant for $25(\mathrm{OH}) \mathrm{D}$ concentrations. We cannot explain differences in $25(\mathrm{OH}) \mathrm{D}$ for adolescents aged 11-13 years with the specific a mounts of the sociodemographic correlates and also not with PA, which might be due to puberty-related changes in physiology and behavior. The health benefits of adequate endurance [58] and normal BMI [59] are well known. Future interventions aiming at improving $25(\mathrm{OH}) \mathrm{D}$ levels, endurance and BMI should focus on children with (non-) immigrant background and lower SES, who bear an increased risk. The association of serum $25(\mathrm{OH}) \mathrm{D}$ with endurance might have effects on muscle function with great importance for public health and physical performance. Therefore, this question needs to be explored in further detail both in mechanistic and in human intervention studies.

\section{Acknowledgment}

We gratefully acknowledge the financial support from Danone GmbH in Germany.

\section{Disclosure Statement}

None of the authors reports any conflict of interest according to the standards of the International Committee of Medical Journal Editors.

\section{References}

1 Heaney RP, Dowell M, Hale C, Bendich A: Calcium absorption varies within the reference range for serum 25-hydroxyvitamin $\mathrm{D}$. J Am Coll Nutr 2003;22:142-146.

2 Bischoff-Ferrari HA: Vitamin D: What is an adequate vitamin $D$ level and how much supplementation is necessary? Best Pract Res Clin Rheumatol 2009;23:789-795.

3 Holick MF: Vitamin D: a delightful health perspective. Nutr Rev 2008;66:182-194.

-4 Bischoff-Ferrari HA, Dawson-Hughes B, Staehelin HB, Orav JE, Stuck AE, Theiler R, Wong JB, Egli A, Kiel DP, Henschkowski J: Fall prevention with supplemental and alpha-hydroxylated vitamin D: a meta-analysis of randomised controlled trials. BMJ 2009;339:b3692.
5 Bischoff-Ferrari HA, Borchers M, Gudat F, Dürmüller U, Stähelin HB, Dick W: Vitamin $D$ receptor expression in human muscle tissue decreases with age. J Bone Mine Res 2004;19:265-269.

6 Gorham ED, Garland CF, Garland FC, Grant WB, Mohr SB, Lipkin M, Newmark HL, Giovannucci E, Wie M, Holick MF: Optimal vitamin D status for colorectal cancer prevention: a quantitative meta analysis. Am J Prev Med 2007;32:210-216.

-7 Chen P, Hu P, Xie D, Qin Y, Wang F, Wang $\mathrm{H}$ : Meta-analysis of vitamin D, calcium and the prevention of breast cancer. Breast Cancer Res Treat 2010;121:469-477.

8 Seidl E: Ultraviolettbestrahlung und Muskeltraining. Strahlentherapie 1956;101:630633.

9 Kersting M, Bergmann K: Die Kalzium- und Vitamin D-Zufuhr von Kindern. Ernährungsumschau 2008;55:525-527.
10 Mensink M, Richter A, Vohmann C, Stahl A, Six J, Kohler S, Fischer J, Heseker H: Forschungsbericht Ernährungsstudie als KiGGS-Modul (EsKiMo). Ernährung Wissenschaft Praxis DOI: 10.1007/s12082-0070048-9.

11 Gordon MC, DePeter KC, Feldman HA, Grace E, Emans SJ: Prevalence of vitamin D deficiency among healthy adolescents. Arch Pediatr Adolesc Med 2004;158:531-537.

$>12$ Sullivan SS, Rosen CJ, Halteman WA, Chen TC, Holick MF: Adolescent girls in Maine are at risk for vitamin D insufficiency. J Am Diet Assoc 2005;105:971-974.

13 Tangpricha V, Pearce EN, Chen TC, Holick MF: Vitamin D insufficiency among freeliving healthy young adults. Am J Med 2002; 112:659-662 
14 Tyvlavsky FA, Cheng S, Lyytikäinen A, Viljakainen $\mathrm{H}$, Lamberg-Allardt C: Strategies to improve vitamin D status in northern European children: exploring the merits of vitamin D fortification and supplementation. J Nutr 2006;136:1130-1134.

15 Hermoso M, Vollhardt C, Bergmann K, Koletzko B: Critical micronutrients in pregnangcy, lactation and infancy: considerations on vitamin $\mathrm{D}$, folic acid, and iron, and priorities for future research. Ann Nutr Metab 2011;59:5-9.

16 Bischoff-Ferrari H: Vitamin D - role in pregnancy and early childhood. Ann Nutr Metab 2011;59:17-21.

-17 Andıran N, Çelik N, Akça H, Doğan G: Vitamin $\mathrm{D}$ deficiency in children and adolescents. Clin Res Pediatr Endocrinol 2012;4: $25-29$.

- 18 Moreno LA, Valtueña J, Pérez-López F, González-Gross M: Health effects related to low vitamin $\mathrm{D}$ concentrations: beyond bone metabolism. Ann Nutr Metab 2011;59:22-27.

-19 McMurray RG, Harrel JS, Bangdiwala SI, Hu $\mathrm{J}$ : Tracking of physical activity and aerobic power from childhood through adolescence. Med Sci Sports Exerc 2003;35:1914-1922.

20 Wagner CL, Greer FR: Prevention of rickets and vitamin D deficiency in infants, children, and adolescents. Pediatrics 2008; 122 : 1142-1152.

-21 Kurth BM: The German Health Interview and Examination Survey for Children and Adolescents (KiGGS): an overview of its planning, implementation and results taking into account aspects of quality management (in German). Bundesgesundheitsblatt Gesundheitsforschung Gesundheitsschutz 2007;50:533-546.

22 Bös K, Worth A, Opper E, Oberger J, Wagner M, Jekauc D, Woll A: The Motoric-Module: Motor Performance Ability and Physical Activity of Children and Adolescents in Germany (in German). Baden-Baden, Nomos, 2009.

23 Kamtsiuris P, Lange M, Schaffrath Rosario A: The German Health Interview and Examination Survey for Children and Adolescents (KiGGS): sample design, response and nonresponse analysis (in German). Bundesgesundheitsblatt Gesundheitsforschung Gesundheitsschutz 2007;50:547-556.

-24 Lange M, Kamtsiuris P, Lange C, Schaffrath Rosario A, Stolzenberg H, Lampert T: Sociodemographic characteristics in the German Health Interview and Examination Survey for Children and Adolescents (KiGGS) - operationalization and public health significance, taking as an example the assessment of general state of health (in German). Bundesgesundheitsblatt Gesundheitsforschung Gesundheitsschutz 2007;50:578589.

25 Treuth MS, Hou N, Young DR, Maynard LM: Validity and reliability of the Fels physical activity questionnaire for children. Med Sci Sports Exerc 2005;37:448-495.
26 President's Council on Physical Fitness and Sports: 2008 physical activity guidelines for Americans. Research Digest 2008, ser 9. http://www.fitness.gov/publications/digests/digest-december2008-508version.pdf. pdf (accessed 23 August 2012).

27 World Health Organization (WHO): Physical activity: a basic requirement for health. 2006. http://www.euro.who.int/mediacentre/PR/2006/20061117_1 (accessed 14 September 2009).

28 Sallis J, Prochaska J, Taylor W: A review of correlates of physical activity of children and adolescents. Med Sci Sports Exerc 2000;32: 963-975.

29 Lämmle L, Tittlbach S, Oberger J, Worth A, Bös K: A two-level model of motor performance ability. J Exerc Sci Fit 2010;8:41-49.

30 Thierfelder W, Dortschy R, Hintzpeter B, Kahl H, Sheidt-Nave C: Biochemical characteristics in the German Health Interview and Examination Survey for Children and Adolescents (KiGGS) (in German). Bundesgesundheitsblatt Gesundheitsforschung Gesundheitsschutz 2007;50:757-770.

31 Hintzpeter B, Scheidt-Nave C, Müller MJ, Schenk L, Mensink GBM: Higher prevalence of vitamin D deficiency is associated with immigrant background among children and adolescents in Germany. J Nutr 2008; 138: 1482-1490.

32 Hu LT, Bentler PM: Cutoff criteria for fit indexes in covariance structure analysis: conventional criteria versus new alternatives. Structural Equation Modeling 1999;6:1-55.

33 Beauducel A, Wittmann WW: Simulation study on fit indexes in CFA based on data with slightly distorted simple structure. Structural Equation Modeling 2005; 12:4175.

34 Arbuckle JL: Full information estimation in the presence of incomplete data; in Marcoulides GA, Schumacker RE (eds): Advanced Structural Equation Modeling. Mahwah, Erlbaum, 1996, pp 243-277.

35 Enders CK, Bandalos DL: The relative performance of full information maximum likelihood estimation for missing data in structural equation models. Structural Equation Modeling 2001;8:430-457.

36 Meade AW, Johnson EC, Braddy PW: Power and sensitivity of alternative fit indices in tests of measurement invariance. J Appl Psychol 2008;93:568-592.

37 Houghton LA, Szymlek-Gay EA, Gray AR, Ferguson EL, Deng X, Heath ALH: Predictors of vitamin $\mathrm{D}$ status and its association with parathyroid hormone in young New Zealand children. Am J Clin Nutr 2010;92: 69-76.
38 Räsanen M, Kronberg-Kippilä C, Ahonen S, Uusitalo L, Kautiainen, Erkkola M, Veijola R, Knip M, Kaila M, Virtanen SM: Intake of vitamin D by Finnish children aged 3 months to 3 years in relation to sociodemographic factors. Eur J Clin Nutr 2006;60:1317-1322.

39 Mowry DA, Costello MM, Heelan KA: Association among cardiorespiratory fitness, body fat, and bone marker measurements in healthy young females. J Am Osteoparth Assoc 2009; 109:534-539.

40 Green J, Waters E, Haikerwal A, O'Neill C, Raman S, Booth ML, Gibbons K: Social, cultural and environmental influences on child activity and eating in Australian migrant communities. Child Care Health Dev 2003; 29:441-448.

-41 Dotevall A, Rosengren A, Lappas G, Wilhelmsen L: Does immigration contribute to decreasing CHD incidence? Coronary risk factors among immigrants in Göteborg, Sweden. J Intern Med 2000;247:331-339.

42 Lindström M, Sundquist J: Immigration and leisure-time physical inactivity: a population-based study. Ethn Health 2001;6:77-85.

43 Hanson MD, Chen E: Socioeconomic status and health behaviors in adolescence: a review of the literature. J Behav Med 2007;25: 425-438.

44 Brunet M, Chaput JP, Tremblay A: The association between low physical fitness and high body mass index or waist circumference is increasing with age in children: the 'Québec en Forme' Project. Int J Obes (Lond) 2007;31: 637-643.

45 Marshall S, Biddle S, Gorely T, Cameron N, Murdey I: Relationships between TV viewing, BMI and physical activity: a meta-analysis. Int J Obes (Lond) 2004;28:1238-1246.

-46 Deforche B, Lefevre J, De Bourdeaudhuij I, Hills AP, Duquet W, Boukaert J: Physical fitness and physical activity in obese and nonobese Flemish youth. Obes Res 2003;11:434441.

47 Racinais C, Hamilton B, Li CK, Grantham J: Vitamin D and physical fitness in Qatari girls. Arch Dis Child 2010;95:854-855.

- 48 Adrestani A, Parker B, Mathur S, Clarkson P, Pescatello LS, Hoffman HJ, Polk DM, Thompson PD: Relation of vitamin D level to maximal oxygen uptake in adults. Am J Cardiol 2011;107:1246-1249.

49 Gilbert-Diamond D, Baylin A, Mora-Plazas M, Marin C, Arsenault JE, Hughes MD, Willett WC, Villamor E: Vitamin D deficiency and anthropometric indicators of adiposity in school-age children: a prospective study. Am J Clin Nutr 2010;92:1446-1451.

50 Conrad A, Seiwert M, Hünken A, Quarcoo D, Schlaud M, Groneberg D: The German Environmental Survey for children (GerES IV): Reference values and distributions for time-location patterns of German children. Int J Hyg Environ Health DOI: 10.1016/j. ijheh.2012.02.004. 
51 Bischoff-Ferrari HA: Vitamin D - role in pregnancy and early childhood. Ann Nutr Metab 2011;59:17-21.

- 52 El Hajj Fuleihan G, Nabulsi M, Tamim H, Maalouf J, Salamoun M, Khalife H, Choucair M, Arabi A, Vieth R: Effect of vitamin D replacement on musculoskeletal parameters in school children: a randomized controlled trial. J Clin Endocrinol Metab 2006;91:405412.

-53 Schoenau E, Neu CM, Mokov E, Wassmer G, Manz F: Influence of puberty on muscle area and cortical bone area of the forearm in boys and girls. J Clin Endocrinol Metab 2000;85: 1095-1098.
54 Schoenau E, Neu CM, Beck B, Manz F, Rauch F: Bone mineral content per muscle crosssectional area as an index of the functional muscle-bone unit. J Bone Miner Res 2002;17: 1095-1101.

55 Mastaglia SR, Seijo M, Muzio D, Somoza J, Nuñez M, Oliveri B: Effect of vitamin D nutritional status on muscle function and strength in healthy women aged over sixtyfive years. J Nutr Health Aging 2011;15:349354.

56 Puthucheary Z, Skipworth JR, Rawal J, Loosemore M, Van Someren K, Montgomery HE: Genetic influences in sport and physical performance. Sports Med 2011;41:845-859.
57 Boland RL: VDR activation of intracellular signaling pathways in skeletal muscle. Mol Cell Endocrinol 2011;347:11-16.

58 Eiberg S, Hasselstrom H, Gronfeldt V, Froberg K, Cooper A, Andersen LB: Physical fitness as a predictor of cardiovascular disease risk factors in 6- to 7-year-old Danish children: the Copenhagen school-child intervention study. Paediatr Exerc Sci 2005; 17: 161-170.

59 Ebbeling CB, Pawlak DB, Ludwig DS: Childhood obesity: public-health crisis, common sense cure. Lancet 2002;360:473-482. 